ISSN 2616-7328 (Online), ISSN 2409-904X (Print)

Kitaêznavčì doslìdžennâ, 2019, No. 1, pp. 76-93

doi: https://doi.org/10.15407/chinesest2019.01.076

UDC: $338.24 .021 .8: 338.22 .021 .4$

\title{
EVOLUTION OF CHINA'S ECONOMIC DEVELOPMENT MODEL
}

\section{O. Drobotiuk}

Ph.D. in Economics,

Kyiv National Economic University named after Vadym Hetman

Institute for Contemporary China Studies named after Borys Kurts

03057, Kyiv, 54/1 Peremohy prospect

khomenko@kneu.edu.ua

This year, the People's Republic of China celebrates its seventieth anniversary. During this period, China has gained a foothold in the global geopolitical and geo-economic arena as a powerful and balanced player that has long-term goals and takes systematic tactical steps to achieve them. The rapid impetus to high economic and social results became possible due to structural reforms initiated forty years ago.

The paper presents a retrospective analysis of the transformation of China's economic model from 1949 to 2019, which identifies three evolutionary stages: the era of accelerated industrialization and the construction of socialism, market transformation and the construction of socialism with Chinese characteristics, innovation-driven economy and the construction of socialism with Chinese characteristics in the new era. The first stage is characterized by a significant economic recovery, growth of per capita income, and the creation of the industrial base for China's further development. However, the growth of the economy has been cyclical because of the economic experiments, wars, and partial isolation from the world. During the second phase, the Chinese government has introduced a number of systemic reforms aimed at developing an open economy, stimulating purchasing power, developing small and medium-sized businesses, creating special economic zones, increasing the innovative competitiveness of companies and regions, increasing investment attractiveness and the like. The third stage is building socialism with Chinese characteristics in the new era: the increase of the openness of the PRC, human-centrism and the construction of middle-class society, the elimination of poverty in rural areas, environmental protection, the formation of a world-class army and an innovative nation.

Keywords: China, economic model, economic reform, Chinese Dream, socialism with Chinese characteristics, Mao Zedong, Deng Xiaoping, Xi Jinping

The People's Republic of China has become one of the leading countries in terms of the size of economy (in 2018 - almost US\$ 14 trillion), the volume of exports and imports (in 2018 - US\$ 2.5 trillion and US\$ 2.1 trillion respectively), foreign direct and foreign investments (in 2018 - US\$2 03.5 billion and US\$ 96.5 billion accordingly), gold and foreign exchange reserves (end of 2018 - US\$ 3.1 trillion, or $26 \%$ of world reserves). According to the level of the stock market capitalization of China ranks second after the USA (in 2018 - US\$ 6.3 trillion, in the United States - US\$30.4 trillion). A significant result of the Chinese government's

C 2019 O. Drobotiuk; Published by the A. Yu. Krymskyi Institute of Oriental Studies, NAS of Ukraine and the Ukrainian Association of Sinologists on behalf of The Chinese Studies. This is an Open Access article distributed under the terms of the Creative Commons Attribution License (https://creativecommons.org/licenses/by-nc-nd/4.0/). 
policy is that Chinese yuan has been added to the basket of key international currencies in 2016, and in 2018 the trade in crude oil futures contracts denominated in yuan was introduced on the Shanghai International Energy Exchange.

Today, China is represented not only with excellent quantitative indicators of economic development, but also with increasing qualitative indicators, in particular - the living standards, education, human development, infrastructure, and the like. China has found "blue oceans" that help to make innovative and technological breakthroughs: artificial intelligence, space research, alternative energetics, new materials, and robotics. This is evidenced by the high positions in the global rankings (table 1).

China ranks in the Global Indexes 2018-2019

Table 1

\begin{tabular}{|c|c|c|c|}
\hline \multirow[t]{2}{*}{ Ranking } & \multicolumn{2}{|c|}{ China's rank } & \multirow[t]{2}{*}{ Change } \\
\hline & 2018 & 2019 & \\
\hline \multicolumn{4}{|c|}{ Global Economic Rankings } \\
\hline Index of Economy Freedom & $110(186)$ & $100(186)$ & +10 \\
\hline The Global Competitiveness Index (WEF) & $28(140)$ & $28(141)$ & 0 \\
\hline IMD World Competitiveness Index & $13(63)$ & $14(63)$ & -1 \\
\hline Easy of Doing Business & $46(190)$ & $31(190)$ & +15 \\
\hline Paying taxes ranking & $114(189)$ & $\mathrm{n} / \mathrm{a}$ & \\
\hline Index of Globalization & $79(203)$ & $\mathrm{n} / \mathrm{a}$ & \\
\hline \multicolumn{4}{|c|}{ Global Innovation Competitiveness Rankings } \\
\hline The Global Innovation Index & $17(126)$ & $14(129)$ & +3 \\
\hline IMD World Digital Competitiveness Index & $30(63)$ & $22(63)$ & +8 \\
\hline Bloomberg innovation index & $19(50)$ & $16(60)$ & +3 \\
\hline \multicolumn{4}{|c|}{ Global Social Development Rankings } \\
\hline Human Development Index (UNDP) & $86(189)$ & $\mathrm{n} / \mathrm{a}$ & +1 \\
\hline The Legatum Prosperity Index & $82(149)$ & $\mathrm{n} / \mathrm{a}$ & \\
\hline Social Progress Index & $87(128)$ & $89(149)$ & -2 \\
\hline Global Peace Index & $116(163)$ & $110(163)$ & +6 \\
\hline
\end{tabular}

China's economic, technological and innovative success is possible due to the consistency of state policy and the ability to respond flexibly to changes, risks, and global challenges. The Chinese model of economic development has undergone a number of transformations, the evolution of which can be divided into three major stages: the era of accelerated industrialization and the construction of socialism, market transformation and the construction of socialism with Chinese characteristics, innovation-driven economy and the construction of socialism with Chinese characteristics in the new era.

Table 2

China's macroeconomic indicators, 1953-2018

\begin{tabular}{|c|c|c|c|c|c|c|c|}
\hline \multirow[t]{2}{*}{ Chairman of PRC } & \multirow[t]{2}{*}{$\begin{array}{c}\text { Mao } \\
\text { Ze- } \\
\text { dong }\end{array}$} & $\begin{array}{c}\text { Hua } \\
\text { Guofeng }\end{array}$ & $\begin{array}{l}\text { Hu Yao- } \\
\text { bang }\end{array}$ & $\begin{array}{c}\text { Zhao } \\
\text { Zi- } \\
\text { yang }\end{array}$ & \multirow[t]{2}{*}{$\begin{array}{l}\text { Jiang } \\
\text { Zemin }\end{array}$} & \multirow[t]{2}{*}{$\underset{\text { Jintao }}{\mathrm{Hu}}$} & \multirow[t]{2}{*}{$\begin{array}{l}\text { Xi Jin- } \\
\text { ping }\end{array}$} \\
\hline & & \multicolumn{3}{|c|}{$\begin{array}{c}\text { Deng Xiaoping } \\
1978-1997\end{array}$} & & & \\
\hline Term length & $\begin{array}{c}1943- \\
1976\end{array}$ & $\begin{array}{c}1976- \\
1981\end{array}$ & $\begin{array}{c}1981- \\
1982 \\
1982- \\
1987\end{array}$ & $\begin{array}{c}1987- \\
1989\end{array}$ & $\begin{array}{c}1989 \\
2002\end{array}$ & $\begin{array}{c}2002- \\
2012\end{array}$ & з 2012 \\
\hline
\end{tabular}




\begin{tabular}{|c|c|c|c|c|c|c|c|}
\hline Average GDP growth (\%) & $6.4^{*}$ & 6.4 & 10.6 & 9 & 9.1 & 10.4 & 7.2 \\
\hline $\begin{array}{l}\text { GDP (current billion } \\
\text { USD) }\end{array}$ & 153.9 & 289.6 & 327.1 & 456.3 & 1470.6 & 8560.5 & 13608.2 \\
\hline $\begin{array}{l}\text { China's share in world GDP } \\
(\%)^{* *}\end{array}$ & 2 & 2 & 2 & 2 & 4 & 11 & 16 \\
\hline GDP per capita (USD) $)^{* *}$ & 164.3 & 287.3 & 294.3 & 395.6 & 1132.4 & 5537.6 & 9770.8 \\
\hline \multicolumn{8}{|l|}{$\begin{array}{l}\text { GDP distribution }{ }^{* *}(\%) \text { by } \\
\text { economic sectors: }\end{array}$} \\
\hline - primary industry & 32.8 & 31.8 & 26.8 & 25 & 15.3 & 10.1 & 7.9 \\
\hline - secondary industry & 45.4 & 46.4 & 43.9 & 43 & 50.4 & 45.3 & 40.5 \\
\hline - tertiary industry & 21.7 & 21.8 & 29.3 & 32 & 34.3 & 44.6 & 61.6 \\
\hline $\begin{array}{l}\text { Foreign direct investment } \\
\text { (inflow, billion USD)** }^{* *}\end{array}$ & $\mathrm{n} / \mathrm{a}$ & 0.3 & 2.3 & 3.4 & 52.7 & 121.1 & 203.5 \\
\hline $\begin{array}{l}\text { Foreign direct investment } \\
\text { (outflow, billion USD) }^{* *}\end{array}$ & $\mathrm{n} / \mathrm{a}$ & $\mathrm{n} / \mathrm{a}$ & 0.7 & 0.8 & 2.5 & 87.8 & 96.5 \\
\hline Export (billion USD) ${ }^{* *}$ & 6.9 & 22 & 39.5 & 52.5 & 325.6 & 2048.7 & 2487.1 \\
\hline Import (billion USD) ${ }^{* *}$ & 6.7 & 22 & 43.2 & 59.1 & 295.2 & 1818.4 & 2135.9 \\
\hline
\end{tabular}

*statistics from $1953^{* *}$ statistics for the end of term length

Source: National Bureau of Statistics of China, UNCTADstat, World Ban

The era of accelerated industrialization and the construction of socialism (1953-1976). On October 1, 1949, at Tiananmen Square in Beijing, Mao Zedong gave a speech on the establishment of the People's Republic of China and the Central People's Government of the PRC. The priority task of the Communist Party of China was the creation of a socialist society and world communism, as well as China's emergence as a world power.

After the establishment of the PRC, the course was set for switching from the traditional economic model based on households to the development of a socialist industrial complex, using direct state control. China became a command economy modeled after the Soviet Union, which provided comprehensive support to the Chinese government, in particular, technical, technological and financial.

The main economic policy of the recovery phase (the 1950s) was aimed at accelerated industrialization, so state investment was directed to the mining and processing industries. These priorities were adopted as a goal for the First Five-Year Plan set for 1953-1957 (table 3). An American economist Barry Naughton in "The Chinese Economy: Transitions and Growth" identifies such key features of the industrialization strategy of the 1950s [Naughton 2007]:

1) heavy industry - a priority sector of the economy;

2) strategic focus on extractive and processing industries;

3) saving done by the state and state-owned enterprises;

4) state investment;

5) the source of demand growth is Chinese industry and government investment projects;

6) slow household income growth;

7) planned management of the economy;

8) limited openness to the world. 
Table 3
Timeline Five-Year Plans for the Social and Economic Development of PRC, 1953-1975

\begin{tabular}{|c|c|c|}
\hline $\begin{array}{c}\text { Five-Year } \\
\text { Plans }\end{array}$ & Key priorities and targets & Results $^{1}$ \\
\hline $\begin{array}{c}\text { First } \\
1953-1957^{2}\end{array}$ & $\begin{array}{l}\text { 1) industrialization: construction of } \\
156 \text { large industrial enterprises (with } \\
\text { the support of the USSR); } 649 \text { large } \\
\text { and medium-sized industrial enter- } \\
\text { prises; } \\
\text { 2) creating a foundation for socialist } \\
\text { industrialization; } \\
\text { 3) development of collective owner- } \\
\text { ship for the reform of agriculture and } \\
\text { handicraft production; } \\
\text { 4) the transition of the national capi- } \\
\text { talist industry to the path of state cap- } \\
\text { italism in order to facilitate the so- } \\
\text { cialist transformation of private } \\
\text { industry and trade. }\end{array}$ & $\begin{array}{l}\text { - the average annual GDP growth rate } \\
\text { was } 9.3 \% \text {; } \\
\text { - nominal GDP increased from } 67.9 \text { bil- } \\
\text { lion yuan to } 106.8 \text { billion yuan; } \\
- \text { in the GDP structure, the share of the } \\
\text { primary sector decreased from } 50.5 \% \text { to } \\
40.3 \% \text {, the secondary and tertiary sectors } \\
\text { increased from } 20.9 \% \text { and } 28.6 \% \text { to } \\
29.7 \% \text { and } 30.1 \% \text { respectively; } \\
- \text { the volume of industrial production } \\
\text { doubled, with an annual increase of } \\
16 \% \text {; } \\
- \text { the largest increase in the production of } \\
\text { coal and steel (production increased from } \\
1.3 \text { million tons in } 1952 \text { to } 5.2 \text { million } \\
\text { tons in } 1957 \text { ); } \\
- \text { exports and imports increased from US\$ } \\
0.8 \text { billion and US\$ } 1.1 \text { billion up to US\$ } \\
2.2 \text { billion and US\$ } 2 \text { billion respectively. }\end{array}$ \\
\hline $\begin{array}{c}\text { Second } \\
1958-1962^{3}\end{array}$ & $\begin{array}{l}\text { 1) continuation of industrial construc- } \\
\text { tion, based on the heavy industry; } \\
\text { 2) promotion of technical moderniza- } \\
\text { tion of the economy; } \\
\text { 3) continuation of socialist reform } \\
\text { through the expansion of the share of } \\
\text { collective property, creation of peo- } \\
\text { ple's communes; } \\
\text { 4) development of industry, agricul- } \\
\text { ture, crafts, transport, and trade; } \\
\text { 5) development of talents through } \\
\text { stimulation of research and develop- } \\
\text { ment; } \\
\text { 6) raising living standards and cul- } \\
\text { tural awareness. }\end{array}$ & $\begin{array}{l}\text { - the average annual GDP growth rate } \\
\text { was negative }-0.6 \% \text {; } \\
\text { - nominal GDP decreased from } 130.7 \text { bil- } \\
\text { lion yuan to } 114.9 \text { billion yuan; } \\
\text { - nominal GDP per capita decreased from } \\
200 \text { yuan to } 173 \text { yuan; } \\
\text { - in the GDP structure, the share of the } \\
\text { secondary sector decreased from } 37 \% \text { to } \\
31.3 \% \text {, the primary and tertiary sectors } \\
\text { increased from } 34.1 \% \text { and } 28.9 \% \text { to } \\
39.4 \% \text { and } 29.3 \% \text { respectively; } \\
\text { - exports and imports decreased from } \\
\text { US\$ } 2.7 \text { billion and US\$ } 2.5 \text { billion up to } \\
\text { US\$ } 1.9 \text { billion and US\$ } 1.7 \text { billion re- } \\
\text { spectively. }\end{array}$ \\
\hline $\begin{array}{c}\text { Third } \\
1966-1970^{4}\end{array}$ & $\begin{array}{l}\text { 1) development of agriculture, solv- } \\
\text { ing problems related to the needs of } \\
\text { the population (food, clothing, etc.); } \\
\text { 2) strengthening national defense } \\
\text { through technological development; } \\
\text { 3) development of the economy of } \\
\text { self-sufficiency and promotion of } \\
\text { quality of goods; } \\
\text { 4) development of transport infra- } \\
\text { structure and trade; }\end{array}$ & $\begin{array}{l}\text { - the average annual GDP growth was } \\
7.4 \% \text {; } \\
\text { - nominal GDP increased from } 186.8 \text { bil- } \\
\text { lion yuan to } 225.3 \text { billion yuan; } \\
\text { - nominal GDP per capita dropped from } \\
254 \text { yuan to } 275 \text { yuan; } \\
\text { - in the structure of GDP, the share of the } \\
\text { primary sector decreased from } 37.6 \% \text { to } \\
35.2 \% \text {, the secondary share increased } \\
\text { from } 38 \% \text { to } 40.5 \% \text {, the share of the }\end{array}$ \\
\hline
\end{tabular}

\footnotetext{
${ }^{1}$ Statistical data: National Bureau of Statistics of China, UNCTADstat, World Bank.

2 [The State Council 2006].

${ }^{3}$ [The State Council 2006a].

${ }^{4}$ [The State Council 2006b].
} 
5) promoting research, education, tertiary one - almost unchanged $(24.4 \%$ and culture. $\quad$ to $24.3 \%$ );

- exports and imports decreased from US\$ 2.7 billion and US\$ 2.5 billion up to US\$ 2.3 billion and US\$ 2.27 billion respectively.

Fourth 1) ensuring the average annual - the average annual GDP growth rate 1971-1975 5 growth rate of gross output of indus- was $5.9 \%$;

try and agriculture in the amount of - nominal GDP increased from 242.6 bil$12.5 \%$;

lion yuan to 299.7 billion yuan;

2) the continuation of infrastructure - nominal GDP per capita decreased from development (public investment - 288 yuan to 327 yuan;

130 billion yuan over five years); $\quad$ - in the structure of GDP, the share of pri3) development of agriculture, heavy mary and tertiary sectors decreased from industry, and energy.

$34.1 \%$ to $32.4 \%$ and $23.8 \%$ to $21.9 \%$ respectively, the secondary increased from $42.2 \%$ to $45.7 \%$;

- exports and imports increased from US\$ 2.8 billion and US\$ 2.2 billion up to US\$ 7.7 billion and US\$ 7.9 billion respectively.

During the period of the First Five-Year Plan, there was the "double peak" in 1953 and 1956 [The State Council 2006]. This was due to the growth of investments on the part of the USSR and China into the construction of large and medium-sized industrial enterprises (figure 1). The average annual growth rate of the Chinese economy in 1953-1957 was $9.3 \%$.

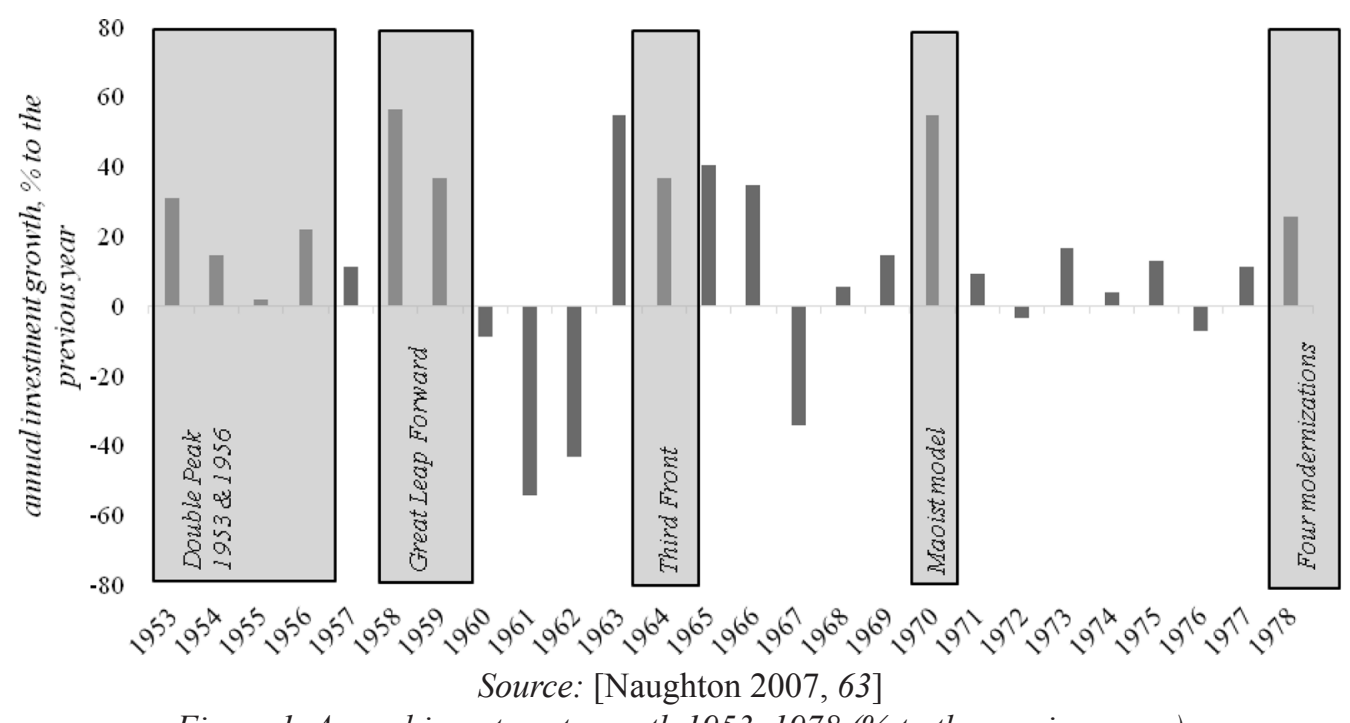

Figure 1. Annual investment growth 1953-1978 (\% to the previous year)

Due to the development of industry, its share in the GDP structure increased from $17.6 \%$ in 1952 to $25.4 \%$ in 1957 . At the same time, the share of construction increased from $3.2 \%$ to $4.3 \%$ over the same period. But the share of agriculture decreased by 10.2 percentage points (from $50.5 \%$ to $40.3 \%$ ), which is explained by the reorientation towards industrialization and its rapid pace.

${ }^{5}$ [The State Council 2006c]. 
The motto of the Great Leap Forward or Second Five-Year Plan (1958-1962) was: "greater, faster, better, cheaper" [The State Council 2006a]. The great leap was designed, first, to create an industrial economy to catch up with the West; secondly, to develop collectivism in a society where socialist principles determine the work, production, and life of people [Cairns 2018].

In general, the Second Five-Year Plan was aimed at the continuation of industrial construction, the beginning of technological modernization, collectivization in agriculture, as well as the development of education, science, and culture. These reforms became the basis for overcoming the consequences of the war, but in the later stages of implementation of the policy, there were economic and social problems - economic imbalance due to the deepening of development of heavy industry, which negatively affected agriculture and agricultural products [Khomenko $2014,85]$. And the average annual rate of decline was $0.6 \%$, the volume of nominal GDP and GDP per capita decreased by $12.1 \%$ and $13.5 \%$, respectively.

In 1964, due to the pressure made by the escalation of the conflict between the United States and Vietnam in the waters of the Gulf of Tonkin, the development strategy of the PRC was changed. The restructuring of the so-called "Third Front", which covered 13 provinces and autonomous regions of China, began (figure 2).

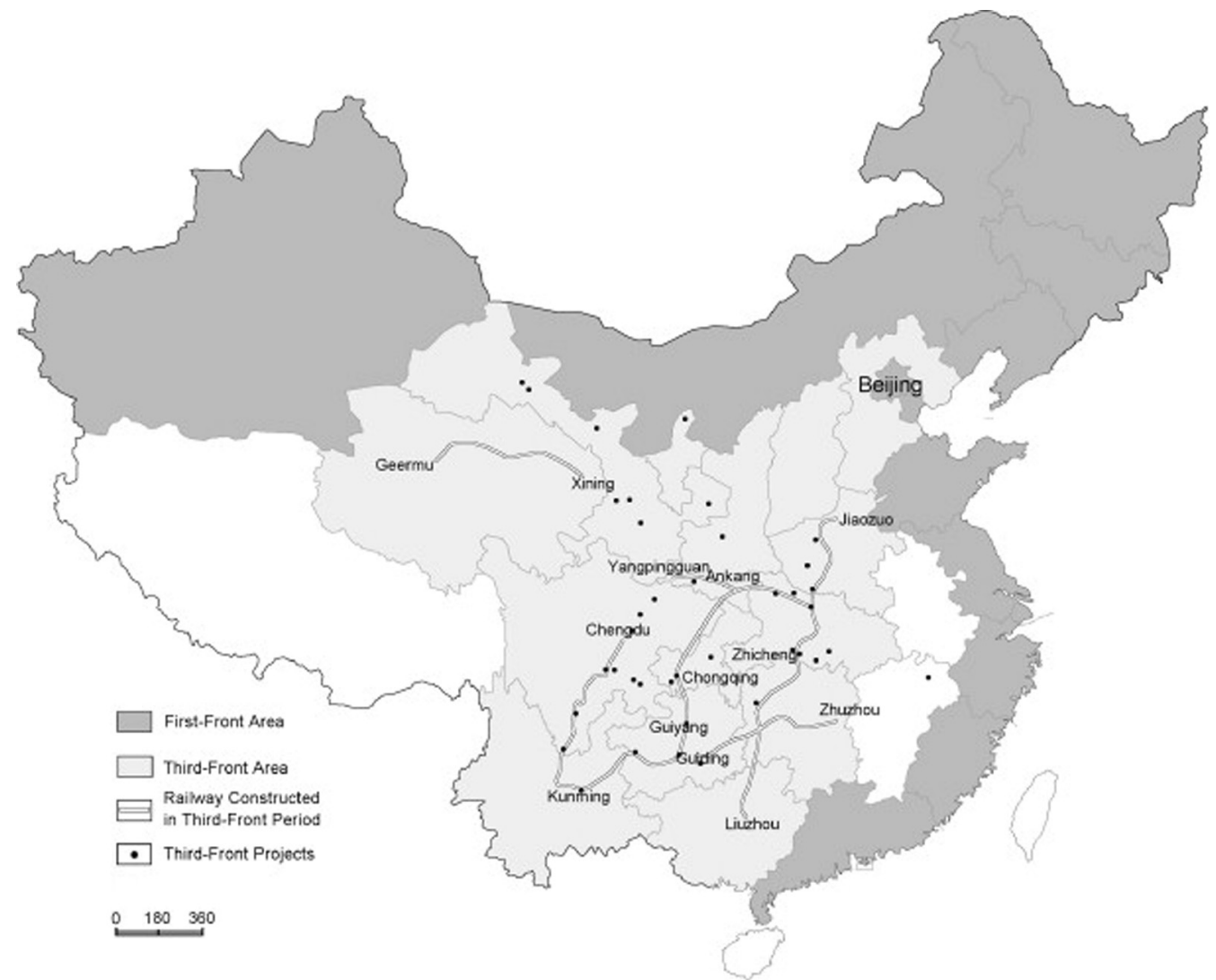

Source: [Li \& Wu 2012]

Figure 2. Third-Front Area and Projects

The construction of the "Third Front" involved large-scale investments in remote areas of Southwestern and Western China in such spheres as national defense, technology, mining, processing, energy, transport, and infrastructure. In 1964, the increase in investment compared to the previous year was $36.4 \%$ (figure 1). The key 
goal was to create a strong production base that would ensure China's strategic independence [Naughton 1988]. With this program, the economy has recovered: the average annual growth rate of real GDP over the period from 1964 to 1966 was $14.1 \%$.

Taking into account the results of the Second Five-Year Plan, the Third FiveYear Plan (1966-1970) was aimed at the development of agriculture (workers that were sent earlier to heavy industry, were returned), industrialization in rural areas (program "Five Small Industries" for agriculture-related industries: the production of ferrous metals, steel, cement, chemical fertilizers, hydropower), and development of consumer goods industries to meet the needs of the population [The State Council 2006b]. The Third Five-Year Plan also provided for the establishment of national defense priorities against the background of possible war: the military-industrial complex, science and technology, industry and transport infrastructure. This period is characterized by the militarization of the economy.

As a consequence of the Third Five-Year Plan, China's economy had an average growth of $7.4 \%$. The slowdown in the economy was observed with the beginning of the "Cultural Revolution": $-5.7 \%$ in 1967 and $-4.1 \%$ in 1968. However, the gross value of industrial and agricultural products exceeded targeted indicators by $14.1 \%$. Nominal GDP and GDP per capita grew by $20.6 \%$ and $8 \%$.

The Fourth Five-Year Plan (1971-1975) was a continuation of the previous five-year plan with a focus on infrastructure development, where the state planned to invest 130 billion yuan over five years [The State Council 2006c]. And also an increase in gross industrial and agricultural production by $12.5 \%$. The most successful years of the Fourth Five-Year Plan were 1973 and 1975, which correspond to the following economic growth rates: $7.9 \%$ and $8.7 \%$.

In 1976, the Fifth Five-Year Plan was launched and it was the last year of the reign of Mao Zedong - the leader of the Chinese Revolution of 1949 and the founder of the PRC. This year was a difficult year for society: The Tiananmen Incident ("counterrevolutionary incident"); the Great Tangshan earthquake, which killed 242,419 people and the city was razed to the ground; and the death of Mao Zedong. Due to these events, China's economy fell by $1.6 \%$ in 1976 [The State Council 2006d].

Summing up the results of the first stage of the evolution of the Chinese economic model the following characteristic features can be distinguished:

1. Development of centrally-controlled economy: no influence of market forces on factors of production, planned the distribution of resources and control over the implementation of plans (the model of the Soviet Union was taken as a basis).

2. Accelerated industrialization: a significant increase in government spending on industrial development, in particular, investment in heavy industry (mining and processing).

3. Collectivization: development of a collective form of ownership for the reform of agricultural and handicraft production, the formation of people's communes.

4. Technological modernization of production: borrowing technology and stimulating the development of science and technology in the country.

5. Militarization of the economy: maintaining a high level of military readiness and defense capacity of the country through the introduction of the investment program "Third Front".

6. Decentralization of economic activity: stimulation of rural industrial development in the 1970s. 
7. Partial isolation from the outside world: foreign economic relations were reduced to a minimum, during the period the Third Five-Year Plan the course was set to develop the economy of self-sufficiency.

Thus, during the period of Mao Zedong's rule, there was a significant economic recovery, growth of per capita income, and the creation of the industrial base for China's further development. However, the growth of the economy has been cyclical because of the economic experiments, wars, and partial isolation from the world [Addison 2007, 13].

The second stage of the evolution of the economic model is the shift from the construction of socialism to the market transformation and the construction of socialism with Chinese characteristics (1978-2012). In 1978, the Third Plenary Session of the $11^{\text {th }}$ Central Committee of the Communist Party of China has launched a policy of reforms and opening up. "Reforms" stood for the weakening of centralized control of economic activities. Also the term "opening up" was explained by the Chinese government as China's integration into the world economy. Before the reforms, the Chinese economy was a closed one, and the share of foreign trade in GDP was $9 \%$.

The first economic reforms were initiated in 1978 in agriculture and addressed the empowerment of rural enterprises. The program of "Four Modernizations" that was scheduled up to 2000 was adopted. It consisted of the following stages: by 1980 - the mechanization of agriculture; by 1985 - completion of the technological restructuring of the national economy on the basis of the provisions of the tenyear plan; by 2000 - being one of the advanced countries in terms of level of development of national economy via modernization of agriculture, industry, defense, science, and technology. The "Four Modernizations" program was aimed at making China a great economic power of the $21^{\text {st }}$ century. In order to accelerate the processes of economic growth, the Chinese government decided to increase the volume of foreign trade by opening its markets. So, by then, the key levers of economic growth were foreign direct investment, an open market, and access to leading technologies.

One of the objectives of the Sixth Five-Year Plan (1981-1985), which was based on the principle "adjust, reform, rectify and improve", was to increase China's exports to international commodity markets, and to attract foreign investment (table 4) [The State Council 2006e]. The Key Technologies Research and Development program was adopted in 1982 in order to develop and introduce innovations.

The creation of special economic zones has become an effective mechanism for achieving these goals. In 1979, the State Council decided to establish four "pilot" special economic zones: Shenzhen, Zhuhai, Xiamen, Guangdong. Pilot SEZs have shown a positive effect on the accumulation of investment and in the increase of industrial production, so in the framework of the implementation of regional policy in 1984, the government opened more special economic zones in 14 coastal cities from Dalian to Beihai. These territories became economic and technological development zones, where the country's technological capacity grew. This corresponds to another goal of the Sixth Five-Year Plan - to encourage technological updating and promote scientific and technological research and application of the latest technologies. Science and technology are recognized as the driving forces of production. The consequence of economic policy in 1981-1985 was the average annual growth rate of the PRC economy of $10.8 \%$, as well as an increase in the share of the service industry in the GDP structure. Due to the opening of special economic zones imports (in particular, technological) increased. 
Table 4

Timeline Five-Year Plans for the Social and Economic Development of PRC, 1976-2010

\begin{tabular}{|c|c|c|}
\hline $\begin{array}{l}\text { Five-Year } \\
\text { Plans }\end{array}$ & Key priorities and targets & Results $^{6}$ \\
\hline $\begin{array}{c}\text { Fifth } \\
1976-1980^{7}\end{array}$ & $\begin{array}{l}\text { 1) realization of } 120 \text { major industrial } \\
\text { projects, including } 10 \text { projects in steel } \\
\text { production, } 9 \text { - non-ferrous metallur- } \\
\text { gy, } 8 \text { - coal industry, } 10 \text { - oil and gas } \\
\text { production; } \\
\text { 2) infrastructure development (state } \\
\text { investment - } 70 \text { billion yuan); } \\
\text { 3) restructuring of the economy. }\end{array}$ & $\begin{array}{l}\text { - the average annual economic growth } \\
\text { rate was } 6.6 \% \text {; } \\
\text { - nominal GDP increased from } 294.4 \text { bil- } \\
\text { lion yuan to } 451.8 \text { billion yuan; } \\
\text { - nominal GDP per capita decreased from } \\
316 \text { yuan to } 460 \text { yuan; } \\
\text { - in the structure of GDP, the share of pri- } \\
\text { mary and tertiary sectors decreased from } \\
32.8 \% \text { to } 30.1 \% \text { and } 21.7 \% \text { to } 21.4 \% \\
\text { respectively, the secondary increased } \\
\text { from } 45.4 \% \text { to } 48.5 \% \text {; } \\
\text { - Exports and imports increased from } \\
\text { US\$ } 6.9 \text { billion and US\$ } 6.7 \text { billion up to } \\
\text { US\$ } 18.1 \text { billion and US\$ } 19.9 \text { billion re- } \\
\text { spectively. }\end{array}$ \\
\hline $\begin{array}{c}\text { Sixth } \\
1981-1985^{8}\end{array}$ & $\begin{array}{l}\text { 1) achieving an average annual } \\
\text { growth rate of } 5 \% \text { for industrial and } \\
\text { agricultural products; } \\
\text { 2) maintaining the supply and quality } \\
\text { of consumer goods in line with the } \\
\text { increase in social purchasing power } \\
\text { and changing the structure of con- } \\
\text { sumption and maintaining market } \\
\text { prices; } \\
\text { 3) reduction of consumption of re- } \\
\text { sources, in particular, energy; } \\
\text { 4) stimulating the introduction of } \\
\text { technological renewal of enterprises } \\
\text { for the purpose of energy-saving; } \\
\text { 5) promotion of research and devel- } \\
\text { opment in the country and active de- } \\
\text { velopment of education, science, and } \\
\text { culture; } \\
\text { 6) development of the national de- } \\
\text { fense industry; } \\
\text { 7) development of trade, the attrac- } \\
\text { tion of foreign capital and its efficient } \\
\text { use; } \\
\text { 8) protection of the environment. }\end{array}$ & $\begin{array}{l}\text { - average annual growth of } 10.8 \% \text {; } \\
\text { - nominal GDP increased from } 486.2 \text { bil- } \\
\text { lion yuan to } 896.44 \text { billion yuan; } \\
\text { - nominal GDP per capita decreased from } \\
489 \text { yuan to } 853 \text { yuan; } \\
\text { - in the structure of GDP, the share of pri- } \\
\text { mary and secondary sectors decreased } \\
\text { from } 31.8 \% \text { to } 28.4 \% \text { and } 46.4 \% \text { to } \\
43.1 \% \text { respectively, tertiary - increased } \\
\text { from } 21.8 \% \text { to } 28.5 \% \text {; } \\
\text { - exports and imports increased from } \\
\text { US\$ } 22 \text { billion and US\$ } 22 \text { billion up to } \\
\text { US\$ } 27.4 \text { billion and US } \$ 42.3 \text { billion re- } \\
\text { spectively. }\end{array}$ \\
\hline $\begin{array}{c}\text { Seventh } \\
\text { 1986-19909 }\end{array}$ & $\begin{array}{l}\text { 1) creating favorable socio-economic } \\
\text { conditions for economic reforms to } \\
\text { ensure a basic balance between social } \\
\text { demand and supply; }\end{array}$ & $\begin{array}{l}\text { - the average annual economic growth } \\
\text { rate of } 7.9 \% \text {; } \\
\text { - nominal GDP grew from } 1 \text { trillion yuan } \\
\text { to } 1.9 \text { trillion yuan; }\end{array}$ \\
\hline
\end{tabular}

\footnotetext{
${ }^{6}$ Statistical data from: National Bureau of Statistics of China, UNCTADstat, World
} Bank.

${ }^{7}$ [The State Council 2006d].

${ }^{8}$ [The State Council 2006e].

${ }^{9}$ [The State Council 2006f]. 
2) formation of a socialist economic - nominal GDP per capita decreased from system with Chinese specificity: reg- 956 yuan to 1634 yuan;

ulation of investments in fixed capital - in the GDP structure, the share of the (energy, communications, telecom- secondary sector decreased from $44 \%$ to munications), technological renewal, $41.6 \%$, the tertiary - increased from reforming and expansion of enter- $28.9 \%$ to $31.3 \%$, the share of the primaprises, further openness to the outside ry sector did not change $-27.1 \%$;

world in combination with internal - exports and imports increased from economic growth and expansion of US\$ 30.9 billion and US\$ 42.9 billion up external economic and technological to US\$ 62.1 billion and US\$ 53.3 billion exchanges; in accordance.

3) promoting the development of science and education.

Eighth 1) deepening policy reforms and $-12 \%$ annual average economic growth; 1991- openness; - nominal GDP grew from 2.2 trillion $\mathbf{1 9 9 5}^{\mathbf{1 0}}$ 2) technological modernization of in- yuan to 5.9 trillion yuan; dustry; $\quad$ nominal GDP per capita decreased from 3) a fourfold increase in GDP; 1879 yuan to 4854 yuan;

4) attracting capital to the industrial - in the structure of GDP, the share of prisector; $\quad$ mary and tertiary sectors decreased from 5) development of large and medium $24.5 \%$ to $20.5 .4 \%$ and $33.4 \%$ to $30.7 \%$ industrial facilities; $\quad$ respectively, the secondary - increased 6) development of transport infra- from $42.1 \%$ to $48.8 \%$;

structure; $\quad$ - exports and imports increased from 7) development of the financial sys- US\$ 71.9 billion and US\$ 63.8 billion up tem; to US\$ 148.8 billion and US\$ 132.1 bil8) development of foreign trade; lion respectively. 9) urbanization.

Ninth 1) completion of the second stage of - average annual economic growth rate 1996- modernization in all directions; was $8.5 \%$;

$\mathbf{2 0 0 0}^{11}$ 2) elimination of poverty, raising the - nominal GDP grew from 6.8 trillion standard of living of the population to yuan to 8.9 trillion yuan; the middle-class; $\quad$-nominal GDP per capita decreased from 3 ) development of modern enter- 5576 yuan to 7858 yuan; prises; $\quad$ - in the GDP structure, the share of the 4) creation of a system of the social- primary sector decreased from $20.4 \%$ to ist market economy. $\quad 16.4 \%$, the secondary and tertiary sectors - increased from $49.5 \%$ and $30.1 \%$ to $50.2 \%$ to $33.4 \%$ respectively;

- exports and imports increased from US\$ 151 billion and US\$ 138.9 billion up to US\$249.2 billion and US\$ 225 billion respectively.

Tenth 1) achieving average annual growth - the average annual growth rate of the 2001- $\quad$ rates of $7 \%$; $\quad$ economy was $9.8 \%$;

$\mathbf{2 0 0 5}^{12}$ 2) maintaining stable prices and - nominal GDP grew from 9.9 trillion maintaining a balance between exter- yuan to 15.9 trillion yuan; nal revenues and expenditures; $\quad$-nominal GDP per capita decreased from 3) optimization and modernization of 8621 yuan to 14185 yuan; the industrial structure, as well as the - in the structure of GDP, the share of

\footnotetext{
${ }^{10}$ [The State Council 2006g].

${ }^{11}$ [The State Council 2006h].

${ }^{12}$ [The State Council 2006i].
} 


\begin{tabular}{|c|c|c|}
\hline & $\begin{array}{l}\text { formation of China's international } \\
\text { competitiveness; } \\
\text { 4) infrastructure development; } \\
\text { 5) urbanization; } \\
\text { 6) development of education, in- } \\
\text { crease of R\&D expenditures ( } 1.5 \% \\
\text { of GDP); } \\
\text { 7) reduction of the population growth } \\
\text { rate; environmental protection: in- } \\
\text { creasing forest cover, reducing pollu- } \\
\text { tion in cities and villages. }\end{array}$ & $\begin{array}{l}\text { primary and secondary sectors decreased } \\
\text { from } 15.8 \% \text { to } 12.1 \% \text { and } 50.1 \% \text { to } \\
47.2 \% \text { respectively, tertiary - increased } \\
\text { from } 34.1 \% \text { to } 40.5 \% \text {; } \\
\text { - exports and imports increased from } \\
\text { US } \$ 266 \text { billion and US } \$ 243.6 \text { billion up } \\
\text { to US } \$ 761.9 \text { billion and US } \$ 659.9 \text { bil- } \\
\text { lion respectively. }\end{array}$ \\
\hline $\begin{array}{c}\text { Eleventh } \\
2006- \\
2010^{13}\end{array}$ & $\begin{array}{l}\text { 1) building a harmonious society; } \\
\text { 2) the transition to an effective } \\
\text { growth model; } \\
\text { 3) optimization and modernization of } \\
\text { industrial structure; } \\
\text { 4) development and implementation } \\
\text { of innovations in agriculture; } \\
\text { 5) achieving balanced development; } \\
\text { 6) supporting for science, technology, } \\
\text { and education; } \\
\text { 7) improving the quality of public } \\
\text { services; } \\
\text { 8) environmental security and effi- } \\
\text { cient resource allocation. }\end{array}$ & $\begin{array}{l}\text { - the average economic growth rate of } \\
11.4 \% \text {; } \\
\text { - nominal GDP grew from } 18.5 \text { trillion } \\
\text { yuan to } 34.1 \text { trillion yuan; } \\
\text { - nominal GDP per capita decreased from } \\
16.5 \text { thousand yuan to } 30 \text { thousand yuan; } \\
\text { - in the structure of GDP the share of pri- } \\
\text { mary and secondary sectors decreased } \\
\text { from } 11.1 \% \text { to } 10.1 \% \text { and } 47.9 \% \text { to } \\
46.7 \% \text { respectively, tertiary - increased } \\
\text { from } 40.9 \% \text { to } 43.2 \% \text {; } \\
\text { - Exports and imports increased from } \\
\text { US\$ } 968.9 \text { billion and US\$ } 791.5 \text { billion } \\
\text { up to US } \$ 1577.8 \text { billion and US\$ } 1,396 \\
\text { billion respectively. }\end{array}$ \\
\hline
\end{tabular}

The Tenth Five-Year Plan (2001-2005) was a continuation of the policy of construction of socialism with Chinese characteristics aimed at increasing economic growth to $7 \%$, retention of unemployment at $5 \%$ level; maintaining price stability and balance of the state budget; continuation of the development of foreign trade and competitiveness in the world market; reduction of the gap between rich and poor, increasing levels of urbanization; an increase in research funding (up to $1.5 \%$ of GDP) and accelerating scientific and technological progress; reducing the population growth rate [The State Council 2006i]. Planned targets were exceeded: real GDP grew by $9.8 \%$, nominal GDP and GDP per capita increased by 1.6 times, and foreign trade volume - by almost 3 times.

The Eleventh Five-Year Plan (2006-2011) was aimed at building a harmonious society, transition to an efficient model of growth; optimization and modernization of the industrial structure; development and implementation of innovations in agriculture; achieving balanced development, support for science, technology and education; improving the quality of public services; environmental safety and efficient allocation of resources [The State Council 2006j].

The Eleventh Five-Year Plan coincided with the global financial crisis, natural disasters in China, but despite this, China has withstood all the tests and achieved significant success: economic growth, the formation of innovativeness of the state, improvement of living standards and saving of energy.

In order to stimulate the development of China's innovation potential and support national innovations through further financial support for existing and successful government programs, the Chinese government adopted the National Medium-

\footnotetext{
${ }^{13}$ [The State Council 2006j].
} 
Long-term Strategic plan of Science and Technology 2006-2020 [Ministry of Science... 2006].

In 2010, the State Council of the PRC decided to accelerate the development of "strategically new industries": energy efficiency and environmental protection, next generation of information technology, production of high technology equipment, new energy, new materials, vehicles that operate using alternative energy [The State Council 2010].

Thus, the period of transformation of the model of economic development from the closed socialist one to the open one with market mechanisms (socialism with Chinese characteristics) is characterized by:

1) reform policy: structural transformations of the economic system and its modernization from agriculture to high-technology industries, development of the service industry and production increase;

2) the policy of openness and integration into the world economy: opening the Chinese economy to foreign investment by the creation of special economic zones, increasing the volume of foreign trade and turning China into a world exporter of consumer goods;

3) science and innovation - driving forces of production: development of own innovations by stimulating basic and applied science (both in research institutes, at the place of production and enterprises), commercialization of innovation in all industrial sectors and agriculture, reform of the system of protection of intellectual property rights and increase in patenting;

4) urbanization: encouraging rural working-age population to move to cities, developing urban infrastructure, developing industry and services (education, medicine, finance and the like), as of 2010 urbanization has reached the level of $48 \%$;

5) quality and standard of living: increasing the level of income of the population, reducing the gap between the poor and the rich, improving the quality of products, taking measures to protect the environment;

6) building a harmonious society: the development of legal and legislative systems (harmonious legal state), maintenance of order and tranquility in the country, the harmonious coexistence of society and the environment, the formation of the middle class.

Thus, the Chinese government has introduced a number of systemic reforms aimed at developing an open economy, stimulating purchasing power, developing small and medium-sized businesses, creating special economic zones, increasing the innovative competitiveness of companies and regions, increasing investment attractiveness and the like. In 2010, China became the world's second-largest economy, after the United States, and this is one of the results of a policy of reform and opening-up.

The third stage of the evolution of the Chinese economic model - the continuation of the construction of socialism with Chinese characteristics in the new era. If Hu Jintao was the ideologist of building a harmonious society, then the ideologist of socialism with Chinese characteristics in the new era is Xi Jinping, who has been the General Secretary of the CPC since 2012.

One of the key differences of Xi Jinping's concept from the previous ones is the promotion of internal development (inclusive development) together with the preservation of China's policy of openness [Khomenko 2018]. Thus the Twelfth FiveYear Plan of 2011-2015 contained the objectives of overcoming inequality and creating an environment for sustainable growth, stimulating domestic consumption and demand, improving social infrastructure (table 5) [The State Council 2011]. 
Table 5

Timeline Five-Year Plans for the Social and Economic Development of PRC, 2011-2020

\begin{tabular}{|c|c|c|}
\hline $\begin{array}{c}\text { Five-Year } \\
\text { Plans }\end{array}$ & Key priorities and targets & Results $^{14}$ \\
\hline $\begin{array}{c}\text { Twelfth } \\
\text { 2011- } \\
\mathbf{2 0 1 5}^{15}\end{array}$ & $\begin{array}{l}\text { 1) the average annual economic growth } \\
\text { rate of } 7.8 \% \text {; } \\
\text { 2) innovation development is a key pri- } \\
\text { ority: increasing scientific and technical } \\
\text { potential; accelerate reforms and devel- } \\
\text { opment of education, human resources, } \\
\text { and facilitate the development of an in- } \\
\text { novative country; } \\
\text { 3) strategic areas of innovative develop- } \\
\text { ment: energy saving, environmental pro- } \\
\text { tection, new-generation information tech- } \\
\text { nology, biotechnology, alternative energy } \\
\text { sources, materials; } \\
\text { 4) promoting the development of inno- } \\
\text { vative enterprises; } \\
\text { 5) raising R\&D expenditures to } 2.2 \% \\
\text { of GDP; } \\
6) \text { increase of the patenting rate to } 3.3 \\
\text { per } 10,000 \text { persons; } \\
\text { 7) expansion of domestic consumer de- } \\
\text { mand. }\end{array}$ & $\begin{array}{l}\text { - the average annual economic growth } \\
\text { rate of } 7.9 \% \text {; } \\
\text { - nominal GDP grew from } 40.2 \text { trillion } \\
\text { yuan to } 68.9 \text { trillion yuan; } \\
\text { - nominal GDP per capita decreased } \\
\text { from } 35.2 \text { thousand yuan to } 50.3 \text { thou- } \\
\text { sand yuan; } \\
\text { - in the structure of GDP, the share of } \\
\text { primary and secondary sectors de- } \\
\text { creased from } 10 \% \text { to } 8.8 \% \text { and } \\
46.6 \% \text { to } 40.9 \% \text { respectively, tertia- } \\
\text { ry - increased from } 43.4 \% \text { to } 50.2 \% \text {; } \\
\text { - exports and imports increased from } \\
\text { US\$ } 1.8 \text { trillion and US\$ } 1.7 \text { trillion up } \\
\text { to US\$ } 2.3 \text { trillion and US\$ } 1.7 \text { trillion } \\
\text { respectively. }\end{array}$ \\
\hline $\begin{array}{c}\text { Thirteenth } \\
2016- \\
\mathbf{2 0 2 0}^{16}\end{array}$ & $\begin{array}{l}\text { 1) comprehensive development of a } \\
\text { middle-class society; } \\
\text { 2) maintaining high economic growth } \\
\text { rates }-6.5 \% \text {; } \\
3 \text { ) innovative development ( } 2.5 \% \text { of } \\
\text { GDP of R\&D expenditure); } \\
\text { 4) raising the standard and quality of } \\
\text { life of the population ( } 6.5 \% \text { increase in } \\
\text { per capita income); } \\
5) \text { improving the quality of the environ- } \\
\text { ment. }\end{array}$ & $\begin{array}{l}\text { - the average annual economic growth } \\
\text { rate of } 6.7 \% \text { in the period } 2016-2018 \text {; } \\
\text { - nominal GDP grew from } 74.4 \text { trillion } \\
\text { yuan to } 90 \text { trillion yuan in } 2018 \text {; } \\
\text { - nominal GDP per capita decreased } \\
\text { from } 35.2 \text { thousand yuan to } 50.3 \text { thou- } \\
\text { sand yuan in } 2018 \text {; } \\
\text { - in the GDP structure, the share of the } \\
\text { primary sector decreased from } 8.6 \% \text { to } \\
7.2 \% \text { in } 2018 \text {, the secondary and ter- } \\
\text { tiary sectors - increased from } 39.9 \% \\
\text { and } 51.6 \% \text { to } 40.7 \% \text { to } 52.2 \% \text { in } \\
2018 \text { respectively; } \\
\text { - exports and imports increased from } \\
\text { US\$ } 2.1 \text { trillion and US\$ } 1.6 \text { trillion up } \\
\text { to US } \$ 2.5 \text { trillion and US\$ } 2.1 \text { trillion } \\
\text { respectively. }\end{array}$ \\
\hline
\end{tabular}

In order to continue the policy of openness in 2013, President Xi Jinping announced the initiative "One Belt One Road". The published Concept of the Initiative presents its general idea: "Championing the ideas of equality, extensive consultation, joint contribution, sharing benefits and all-win while abiding by international norms, based on the reality of each country and through equal-footed consultation, we should

\footnotetext{
${ }^{14}$ Statistical data from: National Bureau of Statistics of China, UNCTADstat, World

${ }^{15}$ [The State Council 2011].

${ }^{16}$ [National Development and Reform Commission 2016].
} Bank. 
actively push forward with all-around pragmatic cooperation with countries along the Belt and Road and give consideration to the interests and aspirations of all parties. With combined efforts, we should promote the innovation and development of an international metrological system, encourage international mutual recognition for metrology, facilitate trade liberalization and contribute to the sustainable development of regional economies and societies." The "One Belt One Road" initiative is a peaceful expanding of the PRC's presence, its culture, traditions, and values.

On May 2015, the Medium-term plan for the development of high-tech industry "Made in China-2025" was adopted in order to break the stereotype of "the world factory that produces cheap, low quality products due to low-cost labour" and to form a new image - of a manufacturer of high value-added products and a country with a developed service industry. This plan focuses on the development of hightech industries, particularly pharmaceuticals, automotive, aerospace, semiconductor industries, IT and robotics.

The Thirteenth Five-Year Plan (2016-2020) continues the policy initiated during the previous five-year plan and defines the following goals of socio-economic development: maintaining economic growth at $6.5 \%$, creating a more inclusive society and improving the living standards, which will ensure the formation of a middle class, food safety and delivery of public services, the development of an innovative nation [National Development... 2016].

At the $19^{\text {th }}$ National Congress of the CPC, Xi Jinping noted that socialism with Chinese characteristics has entered a new era: "<..> This means a great breakthrough of the Chinese nation: country has stood up, lives a better life and turns into a strong and powerful nation that embraces the brilliant prospects of the great rejuvenation of the Chinese nation. This has created entirely new opportunities for countries and nations that want to speed up their development while preserving their independence. Thus, China offers its Chinese wisdom and Chinese development approach to solve problems mankind is facing. The new era will be an era of further great gains of socialism with Chinese characteristics in the new historical conditions. This will be an era of the victorious accomplishment of the task of building a moderately prosperous society and the transition to the comprehensive construction of a modernized socialist state; this is the era of the realization of the Chinese Dream of a great rejuvenation of the Chinese nation made by all the efforts of our people; this is the era of China's gradual movement into the center of international activity and the continuous increase of China's contribution to global development... >" [Xi 2017]. According to Xi Jinping, by 2050 China should become "a rich and powerful, democratic and civilized, harmonious and beautiful modernized socialist state".

In November 2018, Xi Jinping delivered a speech at First China International Import Expo, in which he noted measures for further increase of openness [Xi 2018]:

- stimulation of domestic consumption;

- reduction of duties and facilitation of customs clearance procedures (reduction of import clearance costs);

- further liberalization of the investment climate (protection of foreign investment, the openness of the financial sector, service industry, agriculture, mining, manufacturing, telecommunications, education, medicine, and culture);

- strengthening the protection of intellectual property rights (introduction of a system of fines);

- construction of a free trade port in Hainan province;

- conclusion of multilateral free trade agreements; 
- implementation of the "Eight initiatives" of the Beijing Summit of the Forum on China-Africa Cooperation (industrial promotion, infrastructure connectivity, trade facilitation, green development, capacity building, development of health care, maintaining people-to-people exchanges, maintaining peace and stability);

- further development of the Shanghai Free-Trade Zone;

- holding of the Import Expo.

Integral elements of socialism with Chinese characteristics in the new era: the increase of the openness of the PRC, human-centrism and the construction of middle-class society, the elimination of poverty in rural areas, environmental protection, the formation of a world-class army and an innovative nation.

Over 70 years, the People's Republic of China has made a long way from being an agricultural country to becoming a global economic, innovative and technological leader. This path was full of transformations and reforms, ups and downs in socio-economic development, but today we see the striking successes of this country, as well as the resilience and ability to respond flexibly to external risks. The continuation of the construction of socialism with Chinese characteristics in the new era will ensure the creation of an innovative and middle-class nation. Starting from 2030, the Chinese economy will become the first largest in the world, and in 2050 it will be 1.5 times larger than the American one (according to $\mathrm{PwC}$ forecasts).

\section{ЛІТЕРАТУРА}

$13^{\text {th }}$ Five-Year Plan for Economic and Social Development of the People's Republic of China (2016-2020) // National Development and Reform Commission (NDRC), People's Republic of China. Режим доступу: http://en.ndrc.gov.cn/ newsrelease/201612/P020161207645765233498.pdf

Cairns $R$. The Great Leap Forward // Alpha History. 2018. Режим доступу: https://alphahistory.com/chineserevolution/great-leap-forward/.

Decision of the State Council on Accelerating the Fostering and Development of Strategic Emerging Industries // State Council, № 32. 10.10.2010. Режим доступу: http://www.lawinfochina.com/display.aspx?lib=law\&id=8570.

Key points of the $1^{\text {th }}$ Five-Year Plan. Режим доступу: http://www.gov.cn/ english/2006-03/07/content_246929.htm

Li Y . The transformation of regional governance in China: The rescaling of statehood // Progress in Planning. 2012. № 78.

Major Achievements During 12 ${ }^{\text {th }}$ Five-Year Plan (2011-2015) // The State Council the People's Republic of China. Режим доступу: http://english.gov. $\mathrm{cn} / 12$ thFiveYearPlan/

Medium- Long-term Strategic plan of Science and Technology 2006-2020 // Ministry of Science and Technology of the People's Republic of China, China Science and Technology Newsletter, no. 456, February 9, 2006. Режим доступу: http://www.most.gov.cn/eng/.

Naughton B. The Chinese Economy: Transitions and Growth. Massachusetts, 2007.

Naughton B. The Third Front: Defence Industrialization in the Chinese Interior // The China Quarterly. 1988.

The 10 ${ }^{\text {th }}$ Five-Year Plan (2001-2005). Режим доступу: http://www.gov.cn/ english/2006-04/05/content_245624.htm

The $1^{\text {st }}$ Five-Year Plan (1953-1957). Режим доступу: http://www.gov.cn/ english/2006-04/05/content_245703.htm. 
The $2^{\text {nd }}$ Five-Year Plan (1958-1962). Режим доступу: http://www.gov.cn/ english/2006-04/05/content 245706.htm

The $3^{\text {rd }}$ Five-year Plan (1966-1970). Режим доступу: http://www.gov.cn/ english/2006-04/05/content_245707.htm

The $4^{\text {th }}$ Five-Year Plan (1971-1975). Режим доступу: http://www.gov.cn/ english/2006-04/05/content_245708.htm

The $5^{\text {th }}$ Five-Year Plan (1976-1980). Режим доступу: http://www.china.org. cn/archive/2006-02/10/content_1157615.htm

The $6^{\text {th }}$ Five-Year Plan (1981-1985). Режим доступу: http://www.gov.cn/ english/2006-04/05/content 245699.htm

The $7^{\text {th }}$ Five Year Plan (1986-1990). Режим доступу: http://www.gov.cn/ english/2006-04/05/content_245695.htm

The $8^{\text {th }}$ Five-Year Plan (1991-1995). Режим доступу: http://www.gov.cn/ english/2006-04/05/content_245691.htm

The $9^{\text {th }}$ Five-Year Plan (1996-2000). Режим доступу: http://www.gov.cn/ english/2006-04/05/content_245690.htm

The World in 2050 // РwC. 2018. Режим доступу: https://www.pwc.com/gx/ en/issues/economy/the-world-in-2050.html.

$X i J$. Secure a Decisive Victory in Building a Moderately Prosperous Society in All Respects and Strive for the Great Success of Socialism with Chinese Characteristics for a New Era. Режим доступу: https://www.chinadaily.com. $\mathrm{cn} / \mathrm{m} /$ shandong/yantai/2017-11/04/content_34175088.htm.

$X i$ J. The Governance of China II. Beijing, 2017.

$X i J$. Work Together for an Open Global Economy That is Innovative and Inclusive. Режим доступу: http://www.xinhuanet.com/english/2018-11/05/c_137 583815.htm.

Хоменко О. В. Інклюзивне зростання КНР: соціально-економічний ефект // Україна-Китай. 2018. Режим доступу: http://sinologist.com.ua/homenko-o-vinklyuzyvne-zrostannya-knr-sotsialno-ekonomichnyj-efekt/.

Хоменко $О . В$. Формування інноваційної конкурентоспроможності економіки Китаю: дис. канд. ек. наук: 08.00.02. Київ, 2014.

\section{REFERENCES}

Addison, A. (2007), Chinese Economic Performance in the Long Run, 9602030 AD, Development Centre Studies, OECD Publishing Paris.

Cairns, R. (2018), The Great Leap Forward, available at: https://alphahistory. $\mathrm{com} /$ chineserevolution/great-leap-forward/

Khomenko, O. V. (2014), Formuvannya innovatsiynoyi konkurentospromozhnosti ekonomiky Kytayu, PhD Thesis: 08.00.02, Kyiv National Economic University named after Vadym Hetman, Kyiv.

Khomenko, O. V. (2018), "Inklyuzyvne zrostannya KNR: sotsial'no-ekonomichnyy efekt", Ukrayina-Kytay, available at: http://sinologist.com.ua/homenko-o-vinklyuzyvne-zrostannya-knr-sotsialno-ekonomichnyj-efekt/

Li, Y., \& Wu, F. (2012), "The transformation of regional governance in China: The rescaling of statehood", Progress in Planning, 78(2), pp. 55-99.

Ministry of Science and Technology of the People's Republic of China (2006), "Medium- Long-term Strategic plan of Science and Technology 2006-2020", China Science and Technology Newsletter, 456, available at: http://www.most.gov.cn/ eng/ 
National Development and Reform Commission (2016), $13^{\text {th }}$ Five-Year Plan for Economic and Social Development of the People's Republic of China (20162020), available at: http://en.ndrc.gov.cn/newsrelease/201612/P02016120764576 5233498.pdf

Naughton, B. (1988), "The Third Front: Defence Industrialization in the Chinese Interior", The China Quarterly, pp. 351-386.

Naughton, B. (2007), The Chinese Economy: Transitions and Growth, The MIT Press. Massachusetts.

The State Council (2006j), Key points of the $11^{\text {th }}$ Five-Year Plan, available at: http://www.gov.cn/english/2006-03/07/content_246929.htm

The State Council (2006), The $1^{\text {st }}$ Five-Year Plan (1953-1957), available at: http://www.gov.cn/english/2006-04/05/content_245703.htm.

The State Council (2006a), The $2_{\text {nd }}$ Five-Year Plan (1958-1962), available at: http://www.gov.cn/english/2006-04/05/content_245706.htm

The State Council (2006b), The $3^{\text {rd }}$ Five-Year Plan (1966-1970), available at: http://www.gov.cn/english/2006-04/05/content 245707.htm

The State Council (2006c), The $4^{\text {th }}$ Five-Year Plan (1971-1975), available at: http://www.gov.cn/english/2006-04/05/content_245708.htm

The State Council (2006d), The $5^{\text {th }}$ Five-Year Plan (1976-1980), available at: $\mathrm{http} / / /$ www.china.org.cn/archive/2006-02/10/content 1157615.htm

The State Council (2006e), The $6^{\text {th }}$ Five-Year Plan (1981-1985), available at: http://www.gov.cn/english/2006-04/05/content_245699.htm

The State Council (2006f), The $7^{\text {th }}$ Five-Year Plan (1986-1990), available at: http://www.gov.cn/english/2006-04/05/content_245695.htm

The State Council (2006g), The $8^{\text {th }}$ Five-Year Plan (1991-1995), available at: http://www.gov.cn/english/2006-04/05/content_245691.htm

The State Council (2006h), The $9^{\text {th }}$ Five-Year Plan (1996-2000), available at: http://www.gov.cn/english/2006-04/05/content_245690.htm

The State Council (2006i), The $10^{\text {th }}$ Five-Year Plan (2001-2005), available at: http://www.gov.cn/english/2006-04/05/content_245624.htm

The State Council (2010), Decision of the State Council on Accelerating the Fostering and Development of Strategic Emerging Industries, available at: http:// www.lawinfochina.com/display.aspx?lib=law\&id $=8570$

The State Council (2011), Major Achievements During $12^{\text {th }}$ Five-Year Plan (2011-2015), available at: http://english.gov.cn/12thFiveYearPlan/

Xi, J. (2017), Secure a Decisive Victory in Building a Moderately Prosperous Society in All Respects and Strive for the Great Success of Socialism with Chinese Characteristics for a New Era, available at: https://www.chinadaily.com.cn/m/ shandong/yantai/2017-11/04/content 34175088.htm

Xi, J. (2017), The Governance of China II, Foreign Languages Press Co. Ltd., Beijing.

Xi, J. (2018), Work Together for an Open Global Economy That is Innovative and Inclusive, available at: http://www.xinhuanet.com/english/2018-11/05/c_137 583815.htm

\section{ЕВОЛЮЩІЯ ЕКОНОМІЧНОЇ МОДЕЛІ РОЗВИТКУ КНР}

\section{О. В. Дроботюк}

Цього року Китайська Народна Республіка відзначає сімдесятиріччя з моменту заснування. За цей період Китай закріпився на світовій геополітичній і геоекономічний 
арені як потужний та виважений гравець, який має довгострокові цілі та здійснює системні тактичні кроки для їхнього досягнення. Стрімкий поштовх до високих економічних та соціальних результатів обумовили структурні реформи, розпочаті сорок років тому.

У статті представлено ретроспективний аналіз трансформації економічної моделі КНР з 1949 по 2019 рр., на основі якого виокремлено три еволюційні етапи: епоха прискореної індустріалізації та побудова соціалізму, ринкова трансформація і побудова соціалізму з китайською специфікою, інноваційна економіка і побудова соціалізму 3 китайською специфікою в нову еру. Перший етап характеризується суттєвим відновленням економіки, зростанням доходів на душу населення, створенням промислової бази для подальшого розвитку Китаю. Однак зростання економіки було циклічним, що обумовлено економічними експериментами, війнами та частковою зовнішньоекономічною ізоляцією. Протягом другого етапу уряд КНР запровадив низку системних реформ, спрямованих на розвиток відкритості економіки, стимулювання купівельної спроможності, розвиток малого та середнього бізнесу, спеціальних економічних зон, нарощення інноваційної конкурентоспроможності компаній та регіонів, підвищення інвестиційної привабливості тощо. Третій етап - побудова соціалізму з китайською специфікою у нову еру: розширення відкритості КНР, людиноцентризм та побудова середньозаможного суспільства, ліквідація бідності у сільській місцевості, захист довкілля, формування армії світового класу та інноваційної нації.

Ключові слова: Китай, економічна модель, економічна реформа, Китайська мрія, соціалізм із китайською специфікою, Мао Цзедун, Ден Сяопін, Сі Цзіньпін

\section{ЭВОЛЮЦИЯ ЭКОНОМИЧЕСКОЙ МОДЕЛИ РАЗВИТИЯ КНР}

\section{О. В. Дроботюк}

В этом году Китай отмечает семидесятилетие со дня основания. За этот период Китай закрепился на мировой геополитической и геоэкономической арене как мощный и взвешенный игрок, который имеет долгосрочные цели и осуществляет системные тактические шаги для их достижения. Стремительный толчок к высоким экономическим и социальным результатам обусловили структурные реформы, начатые сорок лет назад.

В статье представлен ретроспективный анализ трансформации экономической модели КНР в период с 1949 по 2019 гг,, на основе которого выделены три эволюционных этапа: эпоха ускоренной индустриализации и построение социализма, рыночная трансформация и построение социализма с китайской спецификой, инновационная экономика и построение социализма с китайской спецификой в новую эру. Первый этап характеризуется существенным восстановлением экономики, ростом доходов на душу населения, созданием промышленной базы для дальнейшего развития Китая. Однако рост экономики был циклическим, что обусловлено экономическими экспериментами, войнами и частичной внешнеэкономической изоляцией. На втором этапе правительство КНР ввело ряд системных реформ, направленных на развитие открытости экономики, стимулирования покупательной способности, развитие малого и среднего бизнеса, специальных экономических зон, наращивание инновационной конкурентоспособности компаний и регионов, повышение инвестиционной привлекательности и тому подобное. Третий этап - построение социализма с китайской спецификой в новую эру: расширение открытости КНР, человекоцентризм и построение среднезажиточного общества, ликвидация бедности в сельской местности, защита окружающей среды, формирование армии мирового класса и инновационной нации.

Ключевые слова: Китай, экономическая модель, экономическая реформа, Китайская мечта, социализм с китайской спецификой, Мао Цзэдун, Дэн Сяопин, Си Цзиньпин

Стаття надійшла до редакиії 5.03.2019 